\title{
Bel ağrısı ve ateş: omurga enfeksiyonları
}

\author{
Lowback pain and fever: spine infections
}

\author{
Akif Albayrak, Mehmet Bülent Balioğlu
}

M. S. Baltalimanı Kemik Hastanesi, İstanbul

\begin{abstract}
Omurga enfeksiyonu, etiyolojik ajana göre piyojenik veya granülomatoz olarak ikiye ayrılır. Piyojenik omurga enfeksiyonları, aynı zamanda spondilodiskit olarak da bilinir. Granülomatoz enfeksiyonda ise, en sık etken olarak tüberküloz basili karşımıza çıkmaktadır. Tüberküloz en sık omurga metafizine yerleşir ve anterior longitudinal bağ altından kraniyal ve kaudal olarak uzanarak, paravertebral abse formasyonu yapar ve bu duruma Pott absesi denir. Düşük virülansa sahip etkenlerin neden olduğu subakut ve kronik enfeksiyonlarda, hastalar inatçı ve sinsi bir bel ve sırt ağrısı şikayeti ile doktora başvurmaktadırlar. Laboratuvar analizinde, ilk başvuruda; \%42 hastada lökosit yükselirken, \%92 hastada eritrosit sedimentasyonu yükselmektedir. C-reaktif protein ise, herhangi bir enfeksiyon veya inflamasyon durumunda, 4-6 saat içinde yükselip, her sekiz saatte bir katlanan bir akut faz reaktanıdır. Pott şüphesi olan hastaların, mutlaka PA akciğer grafisi çekilmelidir. Galyum ve teknesyum sintigrafiler, düz röntgenlerde çok önceden pozitif bulgu verir. Manyetik rezonans görüntüleme, tek başına radyonüklit görüntüleme kadar hassas iken (\%96), aynı zamanda malignite ile enfeksiyonu birbirinden çok yüksek oranda ayırt edebilmektedir (\%93). Piyojenik omurga enfeksiyonlarında medikal tedavi olarak önerilen, 6-8 hafta parenteral antibiyotik tedavisi ve uygun olgularda oral olarak antibiyoterapinin devamıdır. Pott hastalığında ise, yıllar içinde ilaç protokolü değişmekle beraber, altı ay dörtlü, devamında altı ay ikili anti-tbc tedavi uygulanır. Medikal tedavinin etkili olmadığı, ilerleyici nörolojik defisit gelişen veya segmenter instabilitesi bulunan hastalarda, cerrahi tedavi önerilmektedir.
\end{abstract}

Anahtar sözcükler: spondilodiskit; Pott hastalığı; tanı; tedavi; bel ağrısı
Spine infections, according to the etiologic agent, is divided as pyogenic or granulomatous. Pyogenic spine infections are also known as spondylodiscitis. In granulomatous infections, tuberculosis bacillus emerges as the most common cause of the infection. Tuberculosis most commonly settles in the metaphyseal part of the spine. Paravertebral abscess formation to the cranial and caudal lying beneath the anterior longitudinal ligament is called Pott abscess. In case of subacute and chronic infections caused by low virulence microorganisms, patients may consult a doctor with a persistent and insidious low back pain. In the laboratory analysis; increased white blood cells in $42 \%$ and erythrocyte sedimentation increase in $92 \%$ of the patients are seen and the C-reactive protein is an acute phase reactant which increases within 4-6 hours and folding every eight hours if an infection or inflammation occurs. For Pott probability, Chest X-Ray of the patient must be obtained. Gallium and technetium scintigraphy is positive earlier than plain X-rays findings. Magnetic resonance imaging is as sensitive as radionuclide imaging alone (\%96), and it is also possible to distinguish infection and malignancy from each other at a very high rate (\%93). Recommended medical treatment for the Pyogenic infection of the spine is, 6-8 weeks parenteral antibiotics and continuation of antibiotics orally for appropriate cases. For the Pott disease, antibiotic protocol has been changed in following years but it is still four drugs for the first 6 months and two drug antituberculosis for the second 6 months. The cases on which medical treatment is ineffective and progressive neurological deficiency or segmental instability is seen, should be candidate for surgical treatment.

Key words: spondylodiscitis; Pott disease; diagnosis; treatment; low back pain

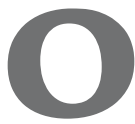

murga enfeksiyonları, etiyolojik olarak piyojenik veya granülomatöz olarak ikiye ayrılmaktadır.

Piyojenik omurga enfeksiyonu (POE), aynı zamanda spondilodiskit olarak da bilinir ve $\% 60$ erkeklerde, ortalama olarak 66 yaş civarında görülür.
Mortaliteyi arttıran faktörler, yüksek C-reaktif protein (CRP) seviyesi ve ileri yaştır. ${ }^{[1]}$

POE, iki yolla oluşabilmektedir. Birincisi hematojen yol, ikincisi ise omurgaya yapılan girişimler esnasında oluşan direkt inokülasyondur. ${ }^{[1]}$

- İletişim adresi: Dr. Akif Albayrak, M. S. Baltalimanı Kemik Hastanesi, Rumelihisarı Cad., Sarıyer, İstanbul Tel: 0532 - 5814629 e-posta: albayrakakif@gmail.com

- Geliş tarihi: 17 A ğustos 2015 Kabul tarihi: 17 Ağustos 2015 
POE'ye neden olan hematojen kaynak, en sık genitoüriner sistem (\%29) ve yumuşak doku enfeksiyonlarıdır (\%11). Genitoüriner sisteme yapılan cerrahi girişimlerde oluşan transiyent bakteriyemiye bağı enfeksiyon, omurgaya ulaşır. End plate ve disk cevresinde yavaşlayan kan akımı, bu bölgelerin enfeksiyonda ilk tutulan bölge olmasına neden olur.

Direkt inokülasyon (\%15-40) nedenleri; lomber ponksiyon, faset enjeksiyonu, laminektomi ve diskektomi gibi cerrahi işlemlerdir. Nadiren de (\%4), retrofarengeal abse veya enfekte aortik graft gibi yakın çevre dokudan da inokülasyon olabilir. ${ }^{[2,3]}$

Granülomatöz omurga enfeksiyonunda en sık karşımıza çıkan etken, Mycobacterium tuberculosis'tir ve Pott absesi olarak da bilinir. En sık omurga metafizine yerleşir ve anterior longitudinal bağ altından kraniyal ve kaudal olarak uzanarak, paravertebral abse formasyonu yapar. POE'den farklı olarak, Pott absesi daha çok torasik yerleşimli olma eğilimindedir.

\section{KLiNiK}

Omurga enfeksiyonlarında klinik seyir, etkenin virülansı ve konağın direncine bağlıdır. Hasta, akut, subakut veya kronik şekilde başvurabilir. Akut evrede başvuran hastaların muayene bulguları; ateş, paravertebral spazm, lokal hassasiyet ve omurgada hareket kısıtlılığıdır. ${ }^{[4]}$

Antibiyotiklerin gelişiminden önce, olguların \%68'i akut evrede gelmekteydi ve çoğunluğunda toksemiye bağlı fulminan tablo izlenmekteydi. Antibiyotiklerin gelişimiyle beraber, enfeksiyona bağlı deformitelerin görünme oranı azalırken, kifoz hala bir miktar karşımıza çıkmaktadır. ${ }^{[5]}$

Başvuruda; ateş hastaların \%52-93'ünde görülür; bel ve boyun ağrısı ise en sık karşılaşılan semptomdur (\%86-90). ${ }^{[1,6]}$ Düşük virülansa sahip etkenlerin neden olduğu subakut ve kronik enfeksiyonlarda, hastalar inatçı ve sinsi bir bel ve sırt ağrısı şikayeti ile doktora başvurmaktadırlar.

Omurgada enfeksiyon; \%48 oranda lomber, \%35 torasik ve $\% 6,5$ servikal, $\% 5$ oranda da torakolomber ve lumbosakral bileşkede görülür. Pott hastalığında ise; hastalar, gece terlemesi ve kilo kaybından daha çok şikayet ederken, $38^{\circ} \mathrm{C}$ üzeri ateş POE'ye göre daha nadir görülmektedir. ${ }^{[1]}$

İnfantlar ve uyuşturucu bağımlılarında, başvuruda farklı şikayetler ve bulgular bulunur. İnfantlarda yüksek ateş, septisemi, genel huzursuzluk ve emmeme bulunur. Uyuşturucu bağımlılarının $\% 81$ 'i, şikayetleri başladıktan üç ay sonra doktora başvururken, bu oran normal popülasyonda \%50'dir. Bu insanların doktora daha erken başvurmalarının nedeni, ağrı eşiklerinin daha düşük olması veya daha fazla narkotik analjeziğe ulaşma arzularına bağlanmıştır. ${ }^{[7]}$

\section{LABORATUVAR BULGULARI}

Laboratuvar analizinde ilk başvuruda; $\% 42$ hastada lökosit yükselirken, \%92 hastada eritrosit sedimentasyonu (ESR) yükselmektedir. C-Reaktif Protein (CRP) ise, herhangi bir enfeksiyon veya inflamasyon durumunda, 4-6 saat içinde yükselip her sekiz saatte bir katlanan ve $36-48$ saatte tepe noktasına ulaşan bir akut faz reaktanıdır. Bu şekliyle, enfeksiyon durumunda ilk yükselen parametre CRP'dir. Yine, yarı ömrü 24-48 saat olduğu için, enfeksiyon takibinde de çok etkilidir. Fakat, CRP akut faz reaktanı olduğundan, inflamasyon yapan her durumda yükselebilir ve cerrahi sonrası 5-10 günde normal değerine iner. ESR de, yine CRP gibi her türlü inflamasyonda ve cerrahi sonrası yükselir; fakat, normal değerine dönmesi 30-40 gün sürer. ${ }^{[5,8]}$ Kan kültürü, ateşin yükseldiği dönemde $\% 58$ hastada pozitiftir. ${ }^{[1]}$ Pott absesi düşünülen hastalarda, PPD (Purified Protein Derivative, saflaştırılmış protein türevi) testi mutlaka yapılmalıdır; PPD testinin amacı, daha önce tüberküloz basiliyle karşılaşılıp karşılaşılmadığını ortaya koymaktır.

\section{GÖRÜNTÜLEME}

Düz grafi bulguları 2-4 haftadan önce oluşmaz. Illk görülen bulgu, disk aralığında daralmadır ve $\% 74$ hastada, başvuruda görülebilir. Servikal bölgede retrofarangeal alanın genişlemesi, torakal bölgede paravertebral gölgenin genişlemesi, lomberde de psoas gölgesi değişiklikleri, abse veya granülasyon dokusu oluşumunu düşündürür.

Pott şüphesi olan hastaların, PA akciğer grafisi mutlaka çekilmelidir.

Galyum ve teknesyum sintigrafiler, düz röntgenlerde çok önceden pozitif bulgu verir. Deneysel çalışmalara bakılırsa, galyum teknesyuma göre daha önce pozitifleşmekteyken, teknesyumun duyarlılık ve doğruluk oranı daha yüksek bulunmuştur.

Bilgisayarlı tomografi (BT) görüntülemede, lomber bölgede disk hipodansitesi enfeksiyon için özgül bir bulgu iken, servikal ve torakalde bu bulguya pek sık rastlanmaz. Tüberküloza has bir diğer bulgu ise, vertebral fragmantasyon ve paraspinal kalsifikasyondur. Destrüksiyonun pediküle uzanması da, piyojenik enfeksiyonda görülmeyen bir durumdur.

Manyetik rezonans (MR) görüntüleme, omurga enfeksiyonlarında bize en fazla bilgiyi sağlayan görüntüleme seçeneğidir. Hem özgüllük hem de duyarlıık olarak 

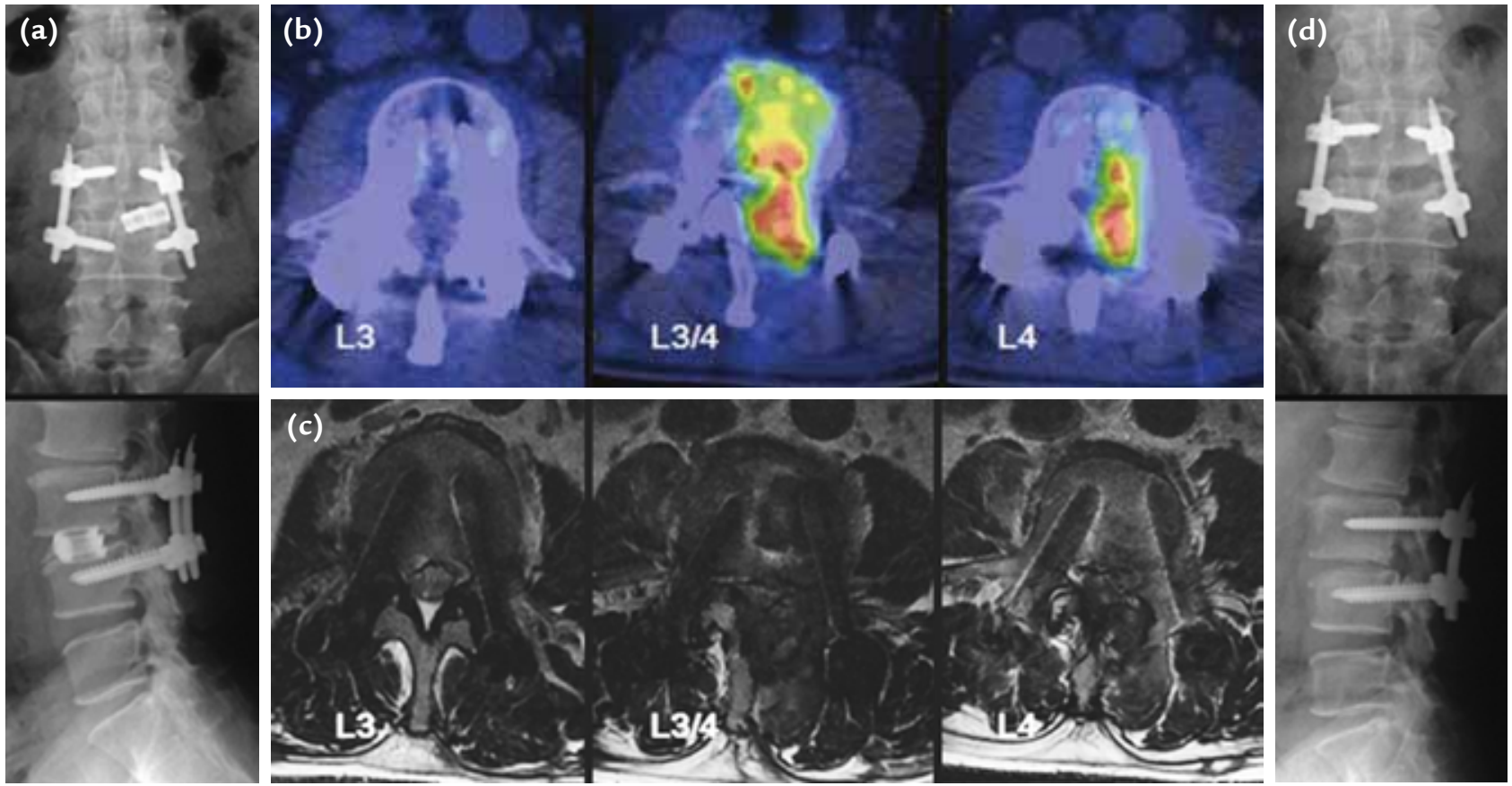

Şekil 1. İmplant ve kafes uygulanmış dejeneratif olgu. MR görüntüsünde net bulgu yokken, PET/CT'de kafes etrafında artmış glukoz tutulumu görülmekte.

en erken ve en kesin bulguları sağlar. MR görüntüleme, tek başına radyonüklit görüntüleme kadar hassas iken (\%96), aynı zamanda malignite ile enfeksiyonu birbirinden çok yüksek oranda ayırt edebilmektedir (\%93). Pott ve POE'de end plate ve disk tutulumu ön plandayken, malignitede korpus tutulumu ve yumuşak dokuya yayılım daha fazladır. Yağ baskılı T2 ve STIR (Short Tau Inversion Recovery) görüntülerde görülen ödem, enfeksiyonun erken bulgusudur. Diskte yükseklik kaybı ve kontrast tutulumu, enfeksiyon için yüksek hassasiyete sahiptir (\%70-100). ${ }^{[1,5]}$ MR'nin dez avantajları ise, tüm iskelet sistemini değerlendirememesi ve serebrospinal sıvının abse ile izointens olmasından ötürü, epidural abse durumunda yanlış negatiflik verebilmesidir.

Piyojenik enfeksiyonla tüberkuloz spondilodiskitin ayrımında MR çok yararlıdır. Enstrümante omurga ameliyatı sonrası oluşabilecek enfeksiyonu ayırt etmede, $M R$, cerrahi sonrası değişikliklerin omurgada mevcut bulunan implantları maskelemesine bağlı olarak, etkili olamamaktadır. Fluorine-18-fluorodeoxyglucose (F-18 FDG) pozitron emisyon tomografi (PET/CT) ise bu konuda oldukça duyarlı ve özgül bulunmuştur (Şekil 1). ${ }^{[9]}$

\section{BIYYPSi}

Kesin tanı için, alınan doku örneğinde etkenin gram boyamada gösterilmesi ve kültürde etkenin üremesi gerekir. Bunun tek istisnası, spondilodiskit semptom ve bulguları bulunan hastada, etkenin kan kültüründen üretilebilmesidir.

Alınan kapalı biyopside üreme olmaması, genellikle hastanın biyopsi esnasında antibiyotik kullanmasına bağlı olmaktadır; bu durumda, tüm antibiyotikler kesilerek biyopsi tekrarı yapılmalıdır. İkinci kapalı biyopside de üreme olmazsa, açık biyopsi düşünülmelidir. ${ }^{[1,5]}$

POE'de en sık etken olarak, Staphilococcus viridans ve aureus (\%32-67) karşımıza çıkar.

Granülomatöz enfeksiyonlarda, patolojik incelemede granülasyon dokusunun görülmesi veya granülasyon görülmeyen fakat kronik iltihap bulguları olan olgularda PCR (Polymerase Chain Reaction)'de bakteri DNA'sının gösterilmesi, tanı koydurucudur. ${ }^{[4]}$

\section{TEDAVi}

POE'de medikal tedavi olarak önerilen, 6-8 hafta parenteral antibiyotik tedavisi ve uygun olgularda oral olarak antibiyoterapinin devamıdır. Pott hastalığında ise, yıllar içinde ilaç protokolü değişmekle beraber, altı ay dörtlü, devamında altı ay ikili anti-tbc tedavi uygulanır; ilaç rezistansı bulunan hastalarda, farklı tedavi rejimleri hastaya göre uygulanabilir. POE'de, tedavi boyunca haftalık Hemogram, ESR ve CRP ile takip 
edilmesi önerilir. Brace kullanımının POE'de tedaviye katkı sağladığına dair herhangi bir kanıt bulunmamasına rağmen, hasta konforu için önerilir. Pott hastalığında ise, anti-tbc tedavi ile beraber breys rutin bir uygulamadır. ${ }^{[1,8]}$

Medikal tedavinin etkili olmadığı, ilerleyici nörolojik defisit gelişen veya segmenter instabilitesi bulunan hastalarda, cerrahi tedavi önerilir. ${ }^{[8,10]}$ Nörolojik durumdan bağımsız olarak, epidural abse mevcudiyeti cerrahi tedavi gerektirir. İnstabilite yaratmayan bir epidural abse, sadece laminektomi ile de tedavi edilebilir. $[1,8]$

Cerrahi tedavide klasik olarak uygulanan ve önerilen, anterior olarak absenin boşaltılması ve füzyon amaçlı otogreft uygulanmasıdır. Anterior girişimin avantajı; devitalize ve sekestre dokuların daha rahat debridmanın yapılabilmesidir. Takipte, gerekli olursa ikinci bir seansta, posteriordan stabilizasyon uygulanması yapılabilir. ${ }^{[5,10]}$ Son yıllarda, aynı seansta hem abse drenajı hem de füzyon amaçlı kafes, otogreft ve enstrümantasyon öneren çalışmalar yayımlanmıştır. ${ }^{[8,11]}$

\section{TARTIŞMA}

Spinal enfeksiyonlar; genellikle yandaş hastalığı bulunan düşkün hastalarda görülen, morbidite ve mortalitesi yüksek hastalıklardır. Kilo kaybı, gece terlemesi, inatçı gece ağrısı, mesane disfonksiyonu, 50 yaş üstü, travma, kanser öyküsü, immünsupresyon ve eyer tarzı uyuşma gibi kırmızı bayrak semptomları olan hastalarda; teşhis için dikkatli ve titiz davranmalı ve olası bir enfeksiyon veya malignite atlanmamalıdır. ${ }^{[12]}$

Ayırıcı tanıda; tüberküloz, fungal enfeksiyonlar, metastatik karsinomlar, multipl miyelom, travma, dejeneratif hastalık, epidural abse ve osteoporotik kırıklar akılda tutulmalıdır. ${ }^{[13]}$ Tedavide, geniş debridman sonrası füzyon amaçlı otogreft kullanımı ve oluşacak bir instabilite için, uygun olgularda enstrümantasyon önerilmektedir. ${ }^{[8,11]}$

\section{KAYNAKLAR}

1. Boody BS, Jenkins TJ, Maslak J, Hsu WK, Patel AA. Vertebral Osteomyelitis and Spinal Epidural Abscess: An Evidencebased Review. J Spinal Disord Tech 2015;28(6):E316-27. CrossRef

2. Adeotoye O, Kupfer R. Streptococcus viridans vertebral osteomyelitis. J R Soc Med 1999;92(6):306-7.

3. Shioya $\mathrm{N}$, Ishibe $\mathrm{Y}$, Kan S, Masuda T, Matsumoto N, Takahashi G, Makabe H, Yamada Y, Endo S. Sternoclavicular joint septic arthritis following paraspinal muscle abscess and septic lumbar spondylodiscitis with epidural abscess in a patient with diabetes: a case report. BMC Emerg Med 2012;12:7.

4. Kang JH, Kim HS, Kim SW. Tuberculous spondylitis after percutaneous vertebroplasty: misdiagnosis or complication? Korean J Spine 2013;10(2):97-100. CrossRef

5. Herkowitz HN, Garfin SR, Eismont FJ, Bell GR, Balderston RA, editors. Rothman-Simeone the Spine, 6th ed. Philadelphia, Pa, USA: Elsevier Saunders; 2011.

6. Suzuki $H$, Shichi $D$, Tokuda $Y$, Ishikawa $H$, Maeno $T$, Nakamura $\mathrm{H}$. Pneumococcal vertebral osteomyelitis at three teaching hospitals in Japan, 2003-2011: analysis of 14 cases and a review of the literature. BMC Infect Dis 2013;13:525. CrossRef

7. Ziu M, Dengler B, Cordell D, Bartanusz V. Diagnosis and management of primary pyogenic spinal infections in intravenous recreational drug users. Neurosurg Focus 2014;37(2):E3. CrossRef

8. Ogden AT, Kaiser MG. Single-stage debridement and instrumentation for pyogenic spinal infections. Neurosurg Focus 2004;17(6):E5.

9. Inanami $\mathrm{H}$, Oshima $\mathrm{Y}$, Iwahori $\mathrm{T}$, Takano $\mathrm{Y}$, Koga $\mathrm{H}$, Iwai $\mathrm{H}$. Role of 18F-fluoro-D-deoxyglucose PET/CT in diagnosing surgical site infection after spine surgery with instrumentation. Spine (Phila Pa 1976) 2015;40(2):109-13. CrossRef

10. Hee HT, Majd ME, Holt RT, Pienkowski D. Better treatment of vertebral osteomyelitis using posterior stabilization and titanium mesh cages.J Spinal Disord Tech 2002;15(2):149-56.

11. Dietze DD Jr, Fessler RG, Jacob RP. Primary reconstruction for spinal infections. J Neurosurg 1997;86(6):981-9.

12. Leerar PJ, Boissonnault W, Domholdt E, Roddey T. Documentation of red flags by physical therapists for patients with low back pain. J Man Manip Ther 2007;15(1):42-9.

13. Tomov M, Mitsunaga L, Durbin-Johnson B, Nallur D, Roberto $R$. Reducing surgical site infection in spinal surgery with betadine irrigation and intra-wound vancomycin powder. Spine (Phila Pa 1976) 2015;40(7):491-9. CrossRef 